\title{
MINAT DAN GAYA BELAJAR ILUSTRATOR DI PULAU JAWA PADA ERA DIGITAL
}

\author{
Hasprita Restiamangastuti Boru Mangunsong \\ Pascasarjana Pendidikan Seni Budaya, Universitas Negeri Surabaya \\ E-mail: resti.mangunsong@gmail.com
}

\begin{abstract}
Abstrak
Kemajuan teknologi membawa masyarakat pada era digital dan budaya siber. Era digital memengaruhi gaya hidup masyarakat termasuk cara mereka belajar. Ilustrator Indonesia telah banyak mengerjakan berbagai proyek milik berbagai negara. Artikel ini bertujuan memaparkan bagaimana para illustrator di Pulau Jawa belajar dan bagaimana teknologi digital memengaruhi gaya belajar mereka. Metode penelitian yang digunakan adalah penelitian kualitatif dengan pendekatan netnografi. Populasinya adalah illustrator yang tinggal di Pulau Jawa dengan teknik accidental sampling dalam menarik sampel. Pengumpulan data dilakukan dengan teknik menyebar angket online, melakukan wawancara dan observasi komunitas ilustrator di grup Facebook "Ilustrator Indonesia". Hasil penelitian menunjukan mayoritas ilustrator memiliki minat tinggi dalam mengembangkan kemampuan iustrasinya terutama dalam pengembangan teknik menggambar. Selain itu gaya belajar dominannya adalah visual namun masih memiliki kemampuan belajar secara auditori dan kinestetik. Dalam kegiatan belajarnya para ilustrator sangat dipengaruhi oleh teknologi digital dan internet. Para ilustrator menggunakan internet terutama Instagram, Youtube dan Pinterest dalam belajar dan menggunakan media sosial di internet untuk membentuk komunitas dan berkomunikasi
\end{abstract}

Kata Kunci: gaya belajar, ilustrator, pendidikan era digital, ilustrator Indonesia

\section{INTEREST AND LEARNING STYLE OF ILLUSTRATORS IN JAVA ISLAND IN THE DIGITAL ERA}

\begin{abstract}
Technological advances have brought society to the digital era and cyberculture. The digital era affects people's lifestyles, including the way they learn. Indonesian illustrators have worked on various projects belonging to various countries. This article describes how illustrators in Java learn and how digital technology affects their learning styles. The research method used is qualitative research with a netnographic approach. The population is illustrators who live in Java with accidental sampling techniques in drawing samples. Data collection was carried out by distributing online questionnaires, conducting interviews, and observing the illustrator community in the Facebook group, "Ilustrator Indonesia". The results showed that the majority of illustrators had a high interest in developing their illustration skills, especially in developing drawing techniques. In addition, the dominant learning style is visual but still has auditory and kinesthetic learning abilities. Illustrators are very much influenced by digital technology and the internet in their learning activities. Illustrators use the internet, especially Instagram, Youtube, and Pinterest, in learning and using social media on the internet to create community and communication
\end{abstract}

Keywords: learning style, illustrator, digital era education, Indonesian illustrator 


\section{PENDAHULUAN}

Belajar merupakan proses seumur hidup yang diperlukan manusia, berapapun usianya dan pekerjaannya. Belajar merupakan salah satu kegiatan pendidikan yang merupakan pembudayaan dan pewarisan budaya dan pengembangan potensi (Suci et al., 2020). Cara dan kebiasaan belajar setiap orang bisa berbeda, dipengaruhi oleh banyak faktor seperti lingkungannya, materi yang dipelajari, modalitas yang dimiliki, dan tipe belajarnya. Perkembangan pembelajaran terus terjadi hingga perubahan besar ketika pandemi Covid-19 terjadi. Pembelajaran digital menjadi metode wajib dilakukan di seluruh sekolah di Indonesia, meskipun sebelumnya telah banyak institusi pendidikan yang menerapkan pembelajaran digital dan daring. Tidak hanya pembelajaran di institusi pendidikan formal, pembelajaran informal dan nonformal telah menggunakan media digital dan internet sebagai alat bantu. Di Indonesia perkembangan digital dan daring dalam pembelajaran memang terasa baru saja terjadi akibat pandemi, namun kehidupan masyarakat telah cukup lama berinteraksi erat dengan digital dan internet terutama di wilayah Indonesia bagian barat. Beberapa hal sehari-hari yang sudah biasa dilakukan dengan media digital adalah memesan makanan, kendaraan, berbelanja, besosialisasi, berkomunikasi, berbagi data dan menikmati hiburan. Menurut (Yunus, 2020) Era digital hal-hal tersebut merupakan suatu tanda bahwa masyarakat telah beralih kepada era digital yang memungkinkan fleksibilitas tempat dan waktu. Era digital ini juga dikenal sebagai era disruptif karena cepatnya inovasi dan perkembangan teknologi (Suryadi, 2020). Ada juga yang mengatakan bahwa hari ini masyarakat ada pada budaya siber karena realitas dalam sosial masyarakat terhubung melalui media siber. Menurut Nasrullah (2020) budaya siber adalah praktik sosial maupun nilai-nilai dari komunikasi dan interaksi antarpengguna yang muncul di ruang siber dari hubungan antarmanusia dan teknologi maupun antarmanusia dengan perantara teknologi. Realitas sosial-siber bisa sama dengan realitas sosial nyata (offline) namun juga dapat berbeda sama sekali. Dalam era budaya siber antara manusia dan mesin saling memengaruhi dan saling terintegrasi.

Telah banyak penelitian mengenai e-learning dan bagaimana generasi net belajar. Generasi net adalah generasi yang sedari kecil telah akrab dengan teknologi digital (Oblinger \& Oblinger, 2005). Generasi net ini mungkin saja berbeda usia dari setiap negara tergantung dari seberapa perkembangan teknologi di negara tersebut. Generasi net lebih menyukai pembelajaran yang aktif, dirinya ikut terlibat, mengetahui berdasarkan praktik dan partisipasi daripada diberi tahu, nyaman mekonstruk pemahamannya sendiri dan menyusun informasi. Hal ini juga selaras dengan pendapat Anugrah (2016) bahwa belajar dengan media ICT juga dapat meningkatkan minat belajar seni bagi anak muda. Era digital dan budaya siber telah membentuk budaya baru di masyarakat termasuk dalam cara masyarakat memperoleh informasi, berkomunikasi dan belajar. Kemajuan teknologi dan meningkatnya literasi digital masyarakat memungkinkan proses belajar terjadi di manapun dan kapanpun. Internet dan teknologi digital memungkinkan seseorang mendapatkan informasi elektronik untuk belajar dengan karakteristik yang menguntungkan seperti akurat, mutakhir, cepat, daya jangkau luas, komprehensif dan selektif (Darmawan, 2016). Seseorang juga memiliki lebih banyak pilihan di mana ia belajar, dengan siapa ia belajar, bagaimana ia belajar, dan apa yang ingin ia pelajari. Saat ini banyak sekali konten belajar di Youtube bahkan beberapa website belajar khusus seperti Ruang_Guru, Sekolah.mu, Cakap, dan beberapa website pendidikan dari luar negeri yang bisa diakses oleh orang Indonesia seperti skillshare.com. Belajar berbasis web dan aplikasi yang menyediakan 
banyak konten belajar dan live stream semakin mudah ditemui dan diakses semua orang, dari yang gratis hingga berbayar. Belajar merupakan proses seumur hidup yang jika seseorang menyadarinya maka seseorang tidak khawatir dengan batasan usia, status dan lokasi untuk mengakses konten belajar dan layanan belajar digital. Seorang yang telah dewasa, tidak di usia sekolah dan telah ada di dunia profesional pun masih dapat mengembangkan dirinya dengan belajar dalam banyak platform belajar digital sesuai dengan kebutuhan dan kemampuannya.

Pembelajaran seni terutama seni rupa juga sangat dipengaruhi oleh perkembangan teknologi digital dan internet. Saat ini banyak konten belajar seni rupa di Youtube, Tiktok, kelas-kelas online gratis hingga berbayar dan website khusus belajar seni seperti skillshare. com. Menurut Soehardjo (2011), pendidikan seni terutama terdiri dari kegiatan kreatif dan apresiatif. Sehingga pembelajaran seni tidak hanya terjadi jika seseorang menonton video tutorial atau mengikuti kelas workshop, namun juga ketika berselancar dalam internet dan menyaksikan banyak karya seni seperti dalam aplikasi Instagram, Pinterest, Artstation, DeviantArt dan lain-lain. Pembelajaran seni akan optimal ketika pembelajar keluar dari kekangan ruang-ruang kelas formal untuk mengembangkan kreativitasnya (Astuti et al., 2021). Ketika menyaksikan karya, maka terjadi kegiatan apresiatif yang dapat menjadi wawasan dan inspirasi bagi pembelajar seni. Dalam era digital, tidak hanya belajar seni saja yang berubah, namun cara pelakunya melakukan eksistensi, juga mencari penghasilan. Di era yang tidak lagi ada batas antarnegara, semua pelaku seni dapat saling terhubung dan dapat melakukan transaksi antarnegara tanpa kehadiran fisik sang seniman dan juga karyanya. Era digital dan budaya siber ini juga memengaruhi para ilustrator dan para pebelajar ilustrator di Indonesia khususnya di Pulau Jawa.
Pada artikel ini, pemaknaan illustrator adalah orang yang membuat ilustrasi. Menurut Talani et al., (2012) ilustrasi adalah gambar yang dicetak untuk menyampaikan pesan ditampilkan secara visual, menjadi elemen estetis dan menjadi daya tarik. Beberapa ilustrator di Indonesia telah cukup lama menggunakan teknologi digital dan internet dalam membuat karya, bereksistensi dan menciptakan pendapatan. Karya-karya ilustrator Indonesia telah banyak dipakai dalam berbaagai kepentingan di dalam negeri maupun luar negeri. Banyak ilustrator Indonesia mengerjakan proyek-proyek penting luar negeri, salah satunya adalah Griselda Sastrawinata yang mengerjakan beberapa ilustrasi di Walt Disney Animation Studio, California, Amerika Serikat. Selain itu banyak ilustrator yang menggambar untuk komik-komik Marvel. Hal ini membuktikan bahwa kemampuan para ilustrator Indonesia sangat mumpuni. Namun di balik pencapaian hebat para ilustrator Indonesia, hanya sedikit yang berhasil membuat namanya sendiri menjadi besar sebagai ilustrator. Mayoritas ilustrator masih bekerja berdasarkan permintaan perusahaan, agensi atau klien sehingga nama perusahaannya atau nama agensinyalah yang menjadi besar. Pekerjaan "menukang" juga kerap terjadi pada ilustrator Indonesia terutama ilustrator kecil yang tidak diberi banyak ruang kreativitas dan hanya menjadi visualisator konsep yang diminta oleh klien.

Gaya belajar merupakan salah satu yang dimiliki oleh setiap individu dalam menyerap, mengatur, dan mengolah informasi yang diterima (Suci et al., 2020). Gaya belajar menjadi kunci kesuksesan belajar seseorang dan masing-masing orang memiliki gaya belajar yang berbeda. Gaya belajar di sini dimaknai sebagai cara seseorang dalam menyerap informasi dan mengolah komunikasi yang cukup konsisten dalam jangka waktu yang lama. Neil D. Fleming telah melakukan pengembangan penelitian mengenai gaya 
belajar sejak 1987 yang terkenal dengan VARK yang merupakan akronim dari Visual, Aural, Read/Write, Kinestetik (N. D. Fleming, 1995)VARK merupakan mode komunikasi dalam belajar berdasarkan modal dan preferensi yang dimiliki oleh masing-masing orang. Pembelajar menggunakan mode itu ketika mendapatkan atau memberi informasi (N. Fleming \& Bonwell, 2019). Dalam Mufidah(2017), gaya belajar dibagi menjadi 3 dengan singkatan VAK yaitu visual, auditori, kinestetik. Gaya belajar visual ditandai dengan ketajaman penglihatan, membutuhkan contoh konkret yang dapat dilihat, memiliki kepekaan yang kuat terhadap warna, memiliki pemahaman yang cukup tentang artistik, memiliki kesulitan berdialog secara langsung, sulit mengikuti anjuran secara lisan dan sering salah menginterpretasikan lisan atau ucapan. Cara belajar di era digital juga sesuai dengan teori belajar Piaget, bahwa untuk dapat belajar materi pembelajaran tidak perlu disampaikan secara utuh, namun pebelajar mekonstruksi dengan pengetahuan yang sudah dimilikinya (Hergenhahn \& Olson, 2008).

Pencapaian-pencapaian yang dipunyai ilustrator di Pulau Jawa serta fenomena yang ada di sekitarnya menarik perhatian penulis tentang bagaimana mereka berlatih dan belajar tentang gambar ilustrasi dan minat belajar mereka. Ilustrator di Pulau Jawa dipilih karena Pulau Jawa telah memiliki fasilitas komunikasi digital yang sangat baik daripada pulau-pulau lainnya di Indonesia. Banyak penelitian mengenai pendidikan seni dalam institusi formal maupun pendidikan seni informal, namun belum ada yang menyinggung bagaimana para praktisi belajar. Mengetahui gaya belajar dan minat para praktisi seni dapat memberi pandangan kepada pendidik seni untuk merancang pembelajaran seni di era digital. Selain itu, hasil penelitian ini dapat menjadi sebuah wawasan tentang bagaimana belajar seni rupa terutama ilustrasi pada era digital serta kritik yang membangun khususnya untuk para ilustrator dan pendidik seni.

\section{METODE}

Metode penelitian yang dilakukan penulis adalah penelitian kualitatif netnografi yaitu mempelajari budaya dan masyarakat yang muncul dari daring, komputer atau komunikasi berbasis internet (Yunus, 2020). Pengumpulan data dilakukan dengan penyebaran angket, wawancara dan observasi pada komunitas ilustrator yang ada di internet. Populasinya adalah ilustrator yang tinggal di Pulau Jawa yang aktif di internet. Sampel diambil dengan teknik accidental sampling, yaitu teknik penentuan sampel berdasarkan kebetulan, yaitu siapa saja yang secara kebetulan/insidental bertemu dengan peneliti dapat digunakan sebagai sampel, bila dipandang orang yang kebetulan ditemui itu cocok sebagai sumber data (Sugiyono, 2017). Accidental sampling dipilih karena populasinya tidak terhitung, terutama banyak ilustrator yang memiliki status pekerjaan resmi lainnya. Penelitian ini bertujuan untuk mendeskripsikan jawaban dari rumusan masalah dan menyimpulkan sifat yang paling umum yang terlihat pada sampel. Angket disebar secara online melalui grup facebook "Illustrator Indonesia" dan rekan sejawat peneliti yang menjadi ilustrator

\section{HASIL DAN PEMBAHASAN \\ Hasil}

Hasil penelitian yang dipaparkan penulis meliputi hasil berupa minat belajar para illustrator dan bagaimana mereka belajar. Hasil yang dipaparkan bersumber dari hasil penelitian angket dan wawancara melalui WhatsApp kepada beberapa orang. Angket telah diisi 52 ilustrator yang tinggal di beberapa kota di Pulau Jawa dan wawancara dilakukan kepada 3 orang dari pengisi angket tersebut. 
Responden angket memiliki beragam latar belakang. Dalam hal usia responden berusia $18-42$ tahun dengan mayoritas berusia 24, 27 dan 30 tahun sebanyak masingmasing $11,5 \%$. Secara wilayah mayoritas responden tinggal di Surabaya (16 orang), Sidoarjo (6 orang) dan Jakarta (4 orang). Hal ini sangat wajar karena penulis memiliki banyak relasi illustrator di Surabaya dan sekitarnya daripada di kota-kota lainnya. Dalam hal lama pengalamannya dalam bidang ilustrasi, mayoritas responden $(32,7 \%)$ telah menggeluti ilustrasi selama 3-5 tahun, 21,2\% memiliki pengalaman $0-2$ tahun, $17,3 \% 6-8$ tahun dan lebih dari 10 tahun, sedangkan $11,5 \%$ berpengalaman selama 8-10 tahun. Mayoritas responden berprofesi utama sebagai illustrator yaitu sebanyak $36,5 \%$, sisanya menjawab pekerjan sampingan, hobi dan ketiganya.

Sebanyak 98,1\% responden mengaku berlatih ilustrasi masih menjadi hal penting untuk dirinya, hanya 1 responden yang menjawab tidak. Mayoritas responden, yaitu $50,9 \%$ melaporkan sering berlatih, sedangkan sisanya jarang, atau menjadikan pekerjaan sekaligus sebagai latihan / belajar. Dalam menjawab topik yang paling sering dipelaja- ri, mayoritas jawaban ada pada Teknik menggambar, kemudian disusul pengembangan konsep dan pemasaran. Dalam hal ini responden dapat memilih lebih dari satu jawaban dan dapat menambahkan jawabannya sendiri. Dari hasil ini dapat dilihat bahwa banyak illustrator yang memiliki fokus lebih pada teknik menggambar ilustrasi. Penulis juga bertanya mengenai ketertarikan mereka untuk mempelajari budaya visual tradisional Nusantara untuk pengayaan gambar ilustrasinya. hasilnya $80,8 \%$ tertarik, $11,5 \%$ mungkin dan $7,7 \%$ tidak tertarik.

Dalam hal gaya belajar, penulis membuat pertanyaan meliputi media apa yang sering dipakai dan diminati oleh mereka. Untuk pertanyaan jenis media yang paling disukai responden dapat memilih lebih dari satu jawaban. Jawaban "gambar diam" paling sering dipilih, kemudian disusul gambar gerak / animasi, buku teks cetak / digital, video rekaman, rekaman tiga dimensi dan terakhir rekaman suara. Hal ini selaras dengan wawancara yang dilakukan penulis dengan 3 orang ilustrator, 2 orang menjadikan ilustrasi sebagai pekerjaan utamanya, sedangkan 1 orang lainnya sebagai pekerjaan sampingan. Ketiganya menjawab bahwa mereka lebih sering me-

Apa yang biasa Anda latih / pelajari dalam kemampuan membuat gambar ilustrasi?

52 jawaban

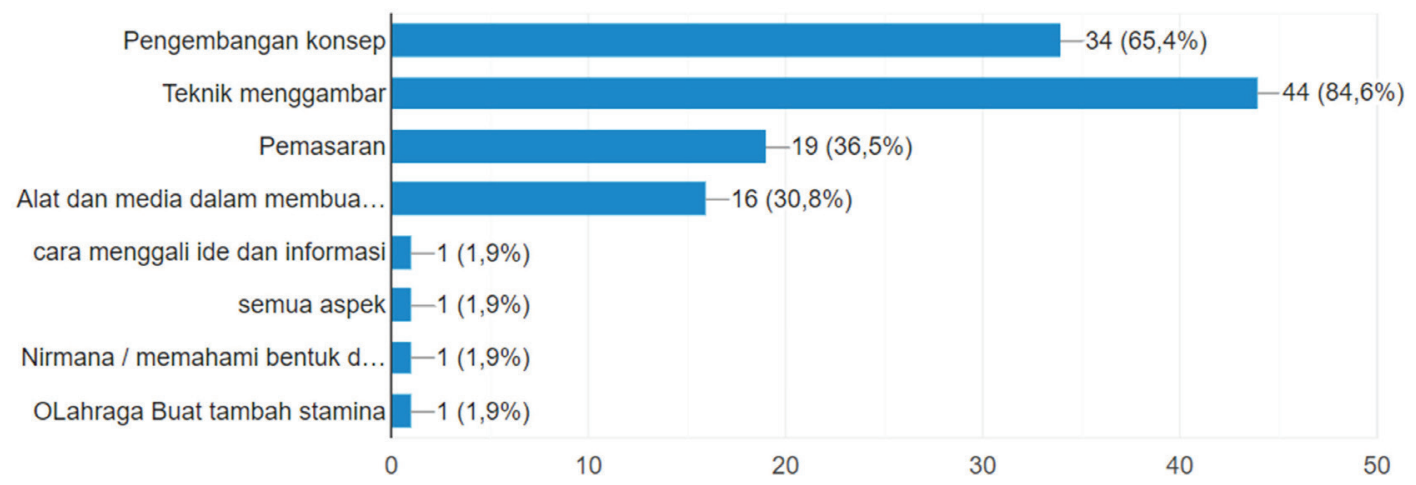

Gambar 1. Topik Belajar yang Diminati Ilustrator 
Apa yang biasa Anda latih / pelajari dalam kemampuan membuat gambar ilustrasi?

52 jawaban

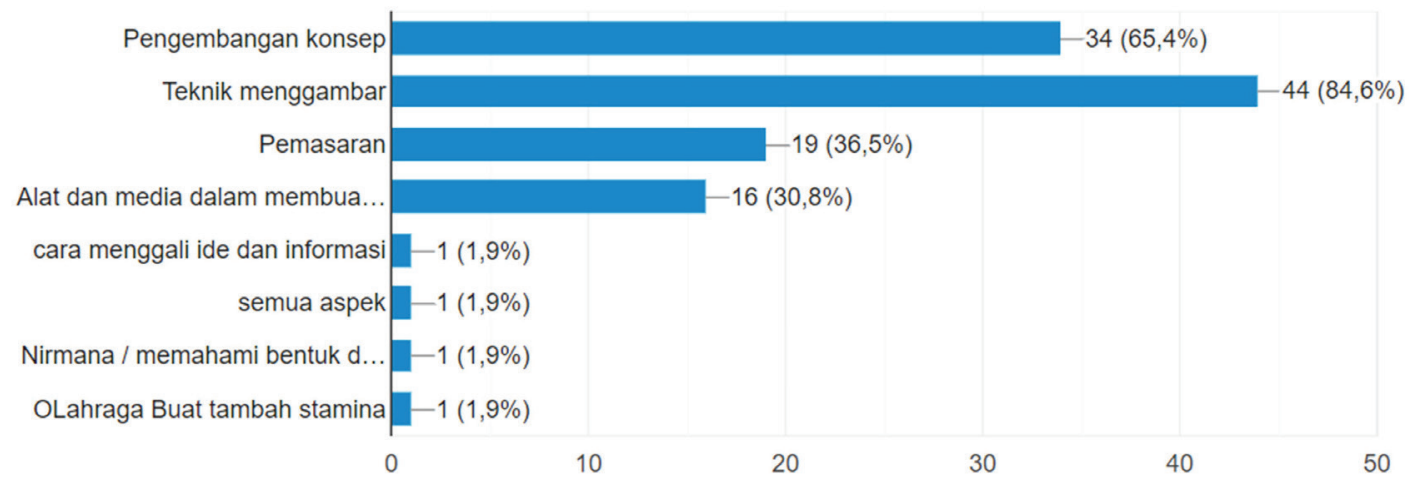

Gambar 2. Jenis Media Belajar yang Diminati Ilustrator

nonton karya-kkarya orang lain di internet, kemudian menelitinya dan mengadopsi serta mengadaptasi hal-hal yang dapat mereka pakai.

Sedangkan untuk jenis pengajaran, yang paling banyak dipilih adalah demonstrasi, kemudian disusul berkarya bersama teman, diskusi dan ceramah, Beberapa responden menambah jenis pengajaran lain antaralain "informasi dari sumber referensi", "tantangan melalui deskripsi / soal lalu diterjemahkan dalam bentuk gambar", dan "dibebaskan"

Mayoritas ilustrator menyukai belajar sendiri $(59,6 \%)$ daripada belajar dengan rekan seperti dengan teman atau mentor. Penulis meminta responden untuk memilih dan menuliskan media apa saja yang paling sering dipakai dalam belajar ilustrasi. Jawaban penulis ringkas dalam tabel 1 .

Cara pengajaran apa yang paling Anda sukai dalam belajar ilustrasi?

52 jawaban

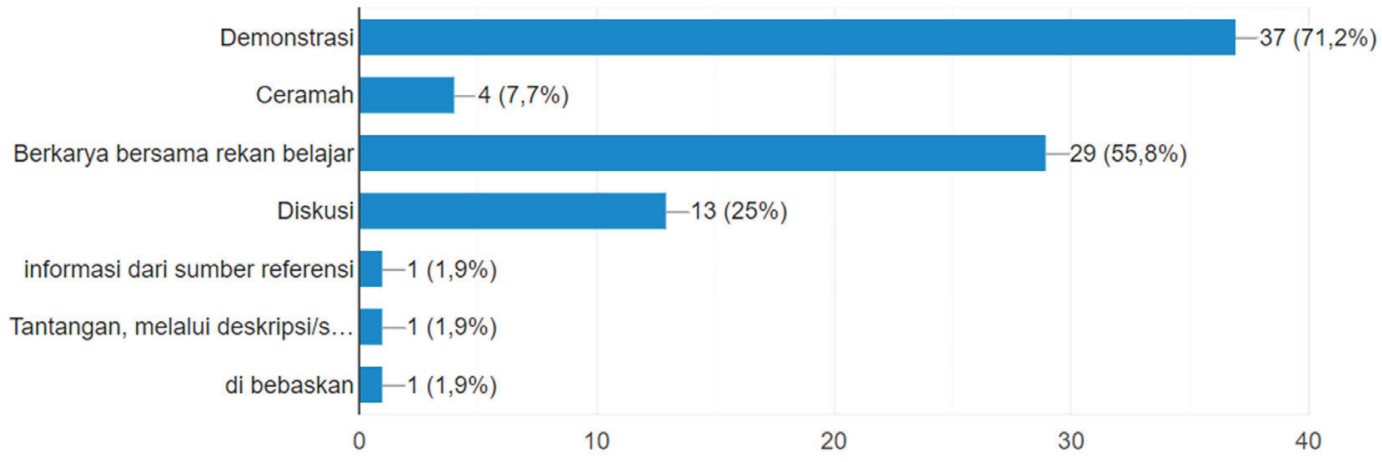

Gambar 3. Cara Pengajaran yang Disukai Ilustrator 
Tabel 1. Media Belajar yang Dipakai

\begin{tabular}{clc}
\hline $\begin{array}{c}\text { Urutan Paling } \\
\text { Sering Dipilih }\end{array}$ & \multicolumn{1}{c}{ Media Belajar } & Banyak Pemilih \\
\hline 1 & Galeri karya dalam website / media sosial & $75 \%$ (39 orang) \\
2 & Video Tutorial & $73,1 \%$ (38 orang) \\
3 & Buku / artikel teks digital & $38,5 \%$ (20 orang) \\
4 & Buku / artikel teks cetak & $21,2 \%(11$ orang) \\
5 & Workshop online / offline & $15,4 \%$ (8 orang) \\
6 & Kelas kursus dalam web & $7,7 \%(4$ orang) \\
7 & Karya orang lain & $1,9 \%(1$ orang) \\
8 & Universitas & $1,9 \%(1$ orang) \\
9 & Les, kursus, tugas kuliah & $1,9 \%(1$ orang) \\
10 & Melihat orang jago gambar melalui video maupun & $1,9 \%(1$ orang) \\
\hline
\end{tabular}

Kemudian penulis meminta responden secara spesifik menuliskan nama web / media belajar yang paling sering dipakai. Karena banyaknya nama web yang disebutkan, penulis meringkasnya dalam table 2 .

Selain melalui angket, penulis juga melakukan observasi dalam beberapa grup illustrator di internet terutama grup facebook "Ilustrator Indonesia". Dalam grup itu tidak terlalu banyak aktivitas pembelajaran gambar ilustrasi yang ditunjukan dan lebih sering kegiatan memamerkan hasil karyanya pada $t i-$ meline grup. Grup tersebut memiliki anggota dari profesional hingga amatir dan memiliki admin sehingga semua post yang masuk dalam grup harus melalui persetujuan para admin. Berdasarkan observasi penulis, beberapa kali admin grup Ilustrator Indonesia mengadakan kelas ilustrasi dengan beberapa tema dan menghadirkan narasumber-narasumber yang profesional di bidang ilusrasi. beberapa dari narasumber tersebut juga adalah anggota dari grup. Setiap kali pendaftaran kelas online dilaksanakan antusias anggota sangat tinggi sehingga tidak jarang anggota grup selalu berebut pendaftaran.

Tabel 2. Nama Media Belajar yang Dipakai

\begin{tabular}{clc}
\hline $\begin{array}{c}\text { Urutan Paling Banyak } \\
\text { Disebutkan }\end{array}$ & Nama Media Belajar & Banyak Responden yang Menyebutkan \\
\hline 1 & Instagram & 18 orang \\
2 & Youtube & 17 orang \\
3 & Pinterest & 12 orang \\
4 & Artstation & 6 orang \\
5 & Facebook & 5 orang \\
6 & Deviantart & 2 orang \\
7 & Google & 2 orang \\
8 & Clip Studio Paint Tutorial Page & 1 orang \\
9 & Kelas / workshop & 1 orang \\
10 & Universitas & 1 orang \\
11 & Twitter & 1 orang \\
12 & Behance & 1 orang \\
13 & Pixiv & 1 orang \\
\hline
\end{tabular}


Secara khusus penulis melakukan wawancara dengan salah satu anggota grup $f a-$ cebook "Ilustrator Indonesia" yaitu Aisyatur Rosyadah illustrator buku anak asal Gresik yang berprofesi utama sebagai guru seni di salah satu SMP Negeri di Gresik. Aisyatur biasanya mengembangkan kemampuan ilustrasinya melalui pencarian referensi karya di Youtube, Instagram dan melihat beberapa buku anak-anak. Aisyatur cukup berminat untuk berdiskusi dan belajar langsung Bersama komunitas ilustrasi namun terhalang oleh kondisi yang tidak mendukungnya untuk dapat keluar rumah. Namun sebagai gantinya, Aisyatur mencari tayangan live atau sisa Youtube live dan mengikuti kelas yang diadakan illustrator. Aisyatur bersyukur karena sejak pandemic, ia dapat mencari konten belajar dengan lebih mudah. Metode pengajaran demonsrasi untuk pengembangan teknis menggambar, merupakan metode favorit Aisyatur dalam mengikuti kelas / konten belajar ilustrasi. Sedangkan untuk pengembangan konsep, secara otomatis terjadi dalam pengajaran demonstrasi tersebut. Wawancara lainnya penulis lakukan dengan Afrizal, seorang illustrator salah satu media koran di Kediri. Dalam memilih media belajar ilustrasi ia mengaku menyukai Instagram dan belajar bersama rekan kerja serta senior-seniornya di kantor tempatnya bekerja. Sedangkan Youtube lebih untuk belajar animasi. Afrizal mengaku sejak memasuki usia kerja ia perlu mengefisienkan waktunya untuk belajar sehingga ia lebih suka melihat karya orang lain langsung sebagai referensi untuk diamati secara mandiri daripada mengikuti kelas, meskipun ia mengaku caranya kurang efektif untuk belajar. Wawancara lainnya penulis lakukan dengan Arfian, seorang pekerja lepas dari Sidoarjo, menjadi illustrator adalah pekerjaan utamanya. Baginya melihat referensi atau karya orang lain dan mengamatinya secara mandiri adalah cara belajar yang efektif. Namun Arfian memberi saran penulis untuk membuat konten video karena baginya video tutorial juga cukup membantu dalam pembelajaran ilustrasi.

\section{Pembahasan}

Era digital dan budaya siber telah memengaruhi hampir keseluruhan kegiatan seorang illustrator khususnya para illustrator yang tinggal di Pulau Jawa. Infratruktur internet telah berkembang baik di Jawa, terutama di kota-kota besar seperti Surabaya, Jakarta dan sekitarnya memungkinkan seorang illustrator menemukan cara belajar yang lebih efisien dengan menggunakan teknologi digital dan internet.

Minat belajar illustrator di Pulau Jawa berdasarkan angket, observasi dan wawancara sangat tinggi. Mereka cukup aktif dengan inisiatif sendiri mencari referensi karya, mengikuti kelas ilustrasi dan menjadi anggota komunitas illustrator. Pada beberapa artefak budaya pada grup Facebook "Ilustrator Indonesia", anggota komunitas aktif mengikuti kelas pelatihan yang diadakan dan menunjukan antusias yang tinggi untuk saling berkomunikasi dan menunjukan hasil karyanya. Berdasarkan angket mereka memiliki minat besar terutama dalam pengembangan teknik menggambar. Hal ini selaras dengan beberapa temuan di internet bahwa para ilustrator lebih suka mengembangkan teknik menggambar mereka daripada pengembangan konsep atau pemasarannya. Temuan ini bisa menjadi penjelas mengapa dengan kehebatan para ilustrator Indonesia, belum ada karya ilustrasi besar yang dikenal sebagai milik Indonesia, karena ilustratornya kurang tertarik menggali pengembangan konsep dan belajar pemasaran karyanya. Hal ini juga menjadi penguat pendapat awal penulis bahwa masih banyak illustrator bekerja berdasarkan deskripsi klien, konsep berdasarkan apa yang klien berikan kemudian ilustrator membuat keputusan artistik berupa tampilan visualnya. 
Gaya belajar dari illustrator mayoritas adalah visual. Hal ini terlihat jelas dari siapa mereka dan jenis media yang paling mereka minati adalah demonstrasi dan referensi karya. Gaya belajar visual salah satunya ditandai dengan kebutuhan untuk melihat / ditunjukan bagaimana cara melakukannya, karena mereka perlu melihat bukti konkret untuk memahami. Selain itu biasanya orang dengan tipe belajar dominan visual kesulitan dalam melakukan komunikasi langsung, sehingga relevan jika para illustrator lebih suka belajar sendiri daripada belajar bersama rekan atau mentor. Mereka juga dapat melakukan pengamatan mandiri terhadap banyak referensi karya / karya orang lain tanpa bantuan dari orang lain untuk menjelaskan. Hal ini karena tipe visual dapat memahami dengan cara melihat, bahkan sering salah menginterpretasikan ucapan lisan dan tidak terlalu terganggu dengan kebisingan. Selain itu keputusan artistik menjadi kelebihan yang dimiliki oleh orang dengan tipe belajar visual, tentu saja para illustrator memiliki kelebihan dalam bidang artistik dan memiliki kepekaan terhadap warna. Meskipun dominan dengan gaya belajar visual, berdasarkan hasil angket, Sebagian kecil illustrator bahkan dapat belajar melalui rekaman audio saja dan nyaman belajar dengan metode diskusi. Selain itu, beberapa illustrator menyukai metode belajar yang langsung mencoba berkarya bersama teman, Hal ini menunjukan bahwa gaya illustrator cenderung visual namun tetap memiliki gaya belajar lainnya / minor yaitu auditori dan kinestetik. Kemandirian belajar para illustrator ini sesuai dengan teori belajar Piaget bahwa pebelajar perlu mekonstruk pemahamannya dengan pengetahuan lama yang telah dimilikinya. Dalam gaya belajar yang dilaporkan illustrator ini terdapat dua kegiatan yang tidak bisa lepas satu dengan yang lain yaitu kegiatan apresiatif dan kreatif. Mayoritas illustrator menyukai menonton karya orang lain di in- ternet yang berarti mereka kerap melakukan kegiatan apresiatif.

Gaya belajar dominan visual pada illustrator ini sangat difasilitasi oleh kemajuan teknologi digital dan internet. Hal ini sejalan dengan diskursus tidak ada batas-batas nyata antara seni dengan ilmu pengetahuan dan teknologi (Wulandari, 2020). Budaya visual saat ini banyak dipengaruhi dan dibentuk oleh apa yang ada di internet seperti media sosial Instagram yang mengekspos konten visual berupa gambar / video daripada tulisan dan suara. Tipe pembelajar mandiri seperti para ilustrator, cocok dengan perkembangan teknologi internet dan digital. Dari jawaban angket yang para ilustrator berikan, nama media belajar yang mereka sebutkan hampir $100 \%$ adalah produk dari internet kecuali "Universitas". Bahkan universitas saat ini juga tidak dapat lepas dari internet sejak pandemi COVID-19. Buku cetak bukan lagi menjadi pilihan media belajar teratas bagi para ilustrator meskipun beberapa masih menggunakannya. Media yang paling banyak digunakan adalah Instagram, Youtube dan Pinterest. Ketiganya memiliki kesamaan yaitu mengekspos visual, mudah dipakai, penggunannya sangat banyak dan dari berbagai negara. Sifat dari informasi elektronik yang mudah diakses, memiliki keterjangkauan yang luas, aktual, dan spesifik berdasarkan kesukaan pengguna menjadi pilihan yang tepat bagi para illustrator yang telah memasuki usia kerja. Banyak illustrator melaporkan bahwa mereka tidak memiliki banyak waktu untuk belajar ilustrasi secara khusus sehingga perlu cara yang benar-benar efisien, mudah dijangkau untuk meningkatkan kemampuan menggambar ilustrasinya. Internet dan teknologi digital yang mendorong masyarakat berinteraksi dalam dunia siber juga menjadi solusi bagi kesibukan para ilustrator. Banyak komunitas-komunitas illustrator di internet terutama media sosial sebagai tempat bagi mereka untuk bereksistensi, belajar dan 
berkomunikasi. Penulis banyak menemui para illustrator aktif pada media sosial dan komunitas ini, seperti menunjukan hasil karya latihannya atau hasil karya kerjanya, saling membagikan tips dan tutorial. Jika dikorelasikan dengan generasi net, tidak semua ilustrator responden masuk dalam generasi net. Namun berdasarkan observasi penulis, mereka tidak mengalami kesulitan dalam mengikuti perkembangan teknologi dan cara bergaul dalam internet dan media sosial. Beberapa ilustrator senior bahkan masih sangat aktif membagikan karyanya di media sosial dan dalam komunitas ilustrator di internet mereka tidak terlihat berbeda dengan generasi yang lebih muda.

\section{KESIMPULAN}

Kemajuan teknologi digital dan internet membawa masyarakat kepada era digital dan era budaya siber. Kegiatan masyarakat banyak beralih dari luring (luar jaringan) ke daring (dalam jaringan). Hal ini juga memengaruhi dunia pendidikan dan bagaimana seseorang belajar. Berkat kemajuan teknologi, semua orang tidak terkendala usia dan status lebih mudah menemukan sumber belajar dan menentukan cara belajarnya sendiri. Indonesia memiliki banyak illustrator hebat yang mengerjakan berbagai proyek di berbagai negara terutama para illustrator di Pulau Jawa yang telah mengenal teknologi digital sejak lama. Bagi para illustrator di Pulau Jawa belajar mengembangkan kemampuan ilustrasi masih sangat penting. Mereka memiliki minat tinggi dalam belajar terutama tentang pengembangan teknik menggambar. Gaya belajar mayoritas para ilustrator adalah visual dengan cara melihat dan mengamati berbagai karya di internet dan menonton video tutorial. Budaya siber dan era digital memengaruhi cara mereka belajar seperti menggunakan Instagram, Youtube dan Pinterest sebagai media belajar yang paling sering mereka pakai. Selain itu para illustrator berkomuni- kasi dan membentuk komunitas di internet dan secara aktif berkegiatan dalam dunia siber. Penelitian ini dapat memberi wawasan bagi penddidik seni rupa atau desain di universitas, sekolah, sanggar maupun komunitas dalam mengembangkan pengajaran gambar ilustrasi. Selain itu juga memberikan wawasan mengenai pengembangan diri kepada para pengiat ilustrasi Kecenderungan generasi milenial untuk menggunakan berbagai sarana digital dan sosial media untuk belajar secara mandiri dapat dimanfaatkan oleh pendidik untuk merancang pendekatan maupun strategi pembelajaran independent berbasis teknologi.

\section{DAFTAR PUSTAKA}

Anugrah, C. D. (2016). Kiat Meningkatkan Minat Belajar Peserta Didik dalam Mata Pelajaran Seni Budaya melalui Media Pembelajaran Berbasis ICT. Imaji, 14(2), 1-18.

Astuti, E. P., Suardana, I. W., Ambarwati, D. R. S., Wulandari, D., \& Isa, B. (2021). Teachers' Perceptions of Museum-Based Learning and Its Effects on Creativity: A Preliminary Study. Proceedings of the 4th International Conference on Arts and Arts Education (ICAAE 2020), 552(ICAAE 2020), 215-221. https:// doi.org/10.2991/assehr.k.210602.043

Darmawan, D. (2016). Pengembangan E-Learning Teori dan Desain. PT Remaja Rosdakarya.

Fleming, N., \& Bonwell, C. (2019). How Do I Learn Best? a Student's Guide to Improved Learning. Neil D Fleming \& Charles Bonwell.

Fleming, N. D. (1995). I'm Different; Not Dumb. Modes of Presentation (V.A.R.K.) in the Tertiary Classroom. Proceedings of the 1995 Annual Conference of the Higher Education and Research Development Society of Australasia, 308-313. 
Hergenhahn, B. R., \& Olson, M. H. (2008). Theories of Learning (7th ed.). KENCANA PRENADA MEDIA GROUP.

Mufidah, L. L. N. (2017). Memahami Gaya Belajar untuk Meningkatkan Potensi Anak. Matabat: Jurnal Perempuan Dan Anak, 1(2), 245-260.

Nasrullah, R. (2020). Etnografi Virtual. Simbiosa Rekatama Media.

Oblinger, D. G., \& Oblinger, J. L. (2005). Educating the Net Generation. EDUCASE E-Book.

Soehardjo, A. J. (2011). Pendidikan Seni: Strategi Penataan dan Pelaksanaan Pembelajaran Seni. Banyumedia Publishing.

Suci, I. G. S., Indrawan, I., Wijoyo, H., \& Kurniawan, F. (2020). Transformasi Digital \& Gaya Belajar. CV. Pena Persada.
Sugiyono. (2017). Metode Penelitian Kuantitatif, Kualitatif, dan R\&D. CV Alfabeta. Suryadi. (2020). Pembelajaran Era Disruptif Menuju Masyarakat 5.0 (Sebuah Telaah Perspektif Manajemen Pendidikan). Seminar Nasional Pendidikan Program Pascasaarjana Universitas PGRI Palembang, 16-29.

Talani, N. S., Sujudi, I., \& Saidi, A. I. (2012). Wacana Visual Ilustrasi Korupsi dalam Rubrik Opini Kompas Periode 2011. Imaji, 10(2), 69-98.

Wulandari, D. (2020). Primary School Students' Perception Of Art and Science Integration In Classroom. Imaji, 18(1), $1-9$.

Yunus, U. (2020). DIGITAL BRANDING: Teori dan Praktik. PT Remaja Rosdakarya Offset. 